\title{
Anticancer Effects of Seaweed-Derived Bioactive Compounds
}

\author{
Heesu Lee ${ }^{1(\mathbb{D})}$, Baskar Selvaraj ${ }^{2,3,4}$ and Jae Wook Lee ${ }^{2,3,4, *}$ \\ 1 Department of Anatomy, College of Dentistry, Gangneung Wonju National University, \\ Gangneung 25457, Korea; nightsu@gwnu.ac.kr \\ 2 Natural Product Research Center, Institute of Natural Product, Korea Institute of Science and Technology, \\ Gangneung 25451, Korea; baskar.203@gmail.com \\ 3 Convergence Research Center of Dementia, Brain Science Institute, Korea Institute of Science and Technology, \\ Seoul 02792, Korea \\ 4 Division of Bio-Medical Science \& Technology, University of Science and Technology, Daejun 34113, Korea \\ * Correspondence: jwlee5@kist.re.kr
}

Citation: Lee, H.; Selvaraj, B.; Lee,

J.W. Anticancer Effects of

Seaweed-Derived Bioactive

Compounds. Appl. Sci. 2021, 11,

11261. https://doi.org/10.3390/

app112311261

Academic Editor: Jae-Ho Park

Received: 31 October 2021

Accepted: 25 November 2021

Published: 27 November 2021

Publisher's Note: MDPI stays neutral with regard to jurisdictional claims in published maps and institutional affiliations.

Copyright: (c) 2021 by the authors. Licensee MDPI, Basel, Switzerland. This article is an open access article distributed under the terms and conditions of the Creative Commons Attribution (CC BY) license (https:/ / creativecommons.org/licenses/by/ $4.0 /)$.

\begin{abstract}
Cancer remains a major life-threatening disease worldwide. The development of anticancer drugs using natural products obtained from marine organisms has been proposed as an alternative approach. Seaweeds are the mainstay of marine ecosystems; therefore, they are highly enriched with diverse bioactive compounds. In the past decade, a vast number of natural compounds, such as polysaccharides, polyphenols, carotenoids, and terpenoids, have been isolated from seaweeds. Seaweeds have bioactive compounds that show cytotoxicity in various cancer cell lines. These compounds prevent tumor growth by inducing apoptotic cell death and arrest growth by interfering with different kinases and cell cycle pathways. This review discussed the anticancer properties of various bioactive compounds isolated from different types of seaweeds and their therapeutic potential against cancers.
\end{abstract}

Keywords: anticancer; seaweeds; polysaccharide; polyphenol; carotenoids; terpenoids

\section{Introduction}

Cancers are serious life-threatening diseases and are regarded as a major public health problem worldwide. It is characterized by an uncontrolled cell growth spreading into the surrounding tissues and the formation of tumor mass [1]. The etiology of cancer is usually multifactorial, and the interaction of many factors causes cancer [2]. The underlying factors causing cancer may include genetic mutations, environmental toxins, hormonal dysregulation, and poor immune conditions [3]. In particular, uncontrolled growth, invasiveness, and metastasis are characteristics of tumor cells evoked by acquired genetic alternations [4]. Tumor development disrupts cellular homeostasis and leads to irregular programmed cell death, signaling pathways and angiogenesis, and weakens the immune response [5]. According to the World Health Organization, 10.1 million new cancer cases were diagnosed worldwide in 2020. In the United States, there will be an estimated 1.9 million new cancer cases, and 608,570 patients are expected to die due to cancer [6].

Cancer can be classified based on its cell type origin or, more recently, using genome analysis [7]. Carcinoma is derived from epithelial cells and is the most common type of cancer, especially in the elderly population. Sarcoma originates from the connective tissues. Lymphoma and leukemia originate from hematopoietic cells. Germ cell tumors are derived from pluripotent cells. Blastoma is common in children and originates from immature embryos. Based on the characteristics and stage of the tumor, cancer treatments are usually a combination of therapies, including chemotherapy, surgery, radiation therapy, and immunotherapy [3]. In all cases, the objective of cancer treatment is to remove the cancer cells without killing normal cells. Chemotherapies are the most popular cancer treatments and include various drug treatments that spread throughout the body tissue. These drugs affect the mode of action in both malignant and healthy cells, and they cause 
various side effects, including anemia, appetite loss, hair loss, peripheral neuropathy, and organ damage [3]. In addition, anticancer drug treatment easily brings about resistance or tolerance, which is one of the main obstacles in chemotherapy.

Although cancer has been investigated for several decades, the development of anticancer drugs that are highly potent, with low tolerance, and that cause fewer side effects is still required. In particular, anticancer drugs that can dramatically improve the median survival rate of cancer patients are yet to be developed, since new anticancer drugs that can improve the quality of life of cancer patients, with highly selective and lower adverse effects, are still lacking. To date, over $60 \%$ of current anticancer drugs have been derived from natural products, which are sources of biologically active compounds. Over the past few decades, research in natural products, especially in the field of anticancer drug development, has given importance to marine sources, particularly seaweeds, because of their large habitats, high biodiversity, and specific living conditions. Anticancer compounds from seaweeds can induce cancer cell death via various signaling pathways and mechanisms [8]. These characteristics of natural products from seaweeds can prevent resistance or tolerance of cancer cells. For instance, fucoidan from seaweeds can act as an anticancer agent through various signaling pathways, including cell cycle arrest, apoptosis, and anti-angiogenesis by inhibiting vascular endothelial growth factor (VEGF) formation, and natural killer (NK) cell activation $[9,10]$.

Several studies have discussed the natural products from seaweeds and their anticancer potentials, as well as the signaling pathways involved in anticancer activity $[8,11-13]$. In this review, we surveyed recent research articles related to seaweeds and their anticancer activity from PubMed. We focused on the chemical structures of the active components that have anticancer potential. Finally, we discussed the detailed structural composition of seaweeds and elucidated the mechanism by which natural products hamper cancer cell growth. Table 1 summarized seaweeds, active ingredients and anticancer activity mentioned in the main text.

Table 1. Cytotoxic marine natural products isolated from seaweeds.

\begin{tabular}{|c|c|c|}
\hline Seaweed & Active Ingredient(s) & Activity \\
\hline Sagassum pallidum & $\begin{array}{l}\text { Highly sulfated polysaccharide SP1, } \\
\text { SP2, and SP3 }\end{array}$ & $\begin{array}{l}\text { Cytotoxicity against A549, HepG2, and } \\
\text { MGC- } 803 \text { cells }\end{array}$ \\
\hline $\begin{array}{l}\text { Dictyopteris delicatula, Dictyopteris } \\
\text { polyodioides }\end{array}$ & Sulfated polysaccharides & $\begin{array}{l}\text { Anticancer activity against HeLa and } \\
\text { RPMI-7951 cells }\end{array}$ \\
\hline $\begin{array}{l}\text { Sargassum hornery, Eclonia cava, and } \\
\text { Costaria costata }\end{array}$ & Fucoidan (3) & $\begin{array}{l}\text { Inhibiting colony formation of melanoma } \\
\text { (SK-MEL-28 cells) and colon cancer cells } \\
\text { (DLD-1 cells) }\end{array}$ \\
\hline Coccophora langsdorfii & $\begin{array}{l}\text { Fucoidan (3), laminarin (1), and } \\
\text { alginate (2) }\end{array}$ & $\begin{array}{l}\text { Anticancer activity against SK-ML-5 and } \\
\text { SK-ML-28 melanoma cells }\end{array}$ \\
\hline Laminaria difitata & Laminarin (1) & $\begin{array}{l}\text { Induction of apoptosis via the ErbB signal } \\
\text { pathway in colon cancer cells }\end{array}$ \\
\hline Ecklonia cava & Dieckol (14) & $\begin{array}{l}\text { Inducing apoptosis and inhibited the growth of } \\
\text { human pancreatic cancer cells PANC-1, } \\
\text { inhibition of non-small-cell lung cancer }\end{array}$ \\
\hline Laminaria japonica & Phlorotannin-rich fraction & $\begin{array}{l}\text { Inhibits BEL-7402 human hepatocellular } \\
\text { carcinoma cells }(30 \%) \text { and P388 murine } \\
\text { leukemic cells }(43 \%) \text { at } 100 \mu \mathrm{g} / \mathrm{mL} \\
\text { concentration }\end{array}$ \\
\hline Ecklonia cava & Phloroglucinol (7) & $\begin{array}{l}\text { Induction of apoptosis in HT- } 29 \text { cells, } \\
\text { decreasing CD } 44(+) \text { cancer cells and cancer } \\
\text { stem cells, inhibition of KRAS and its } \\
\text { downstream regulators in breast cancer stem } \\
\text { like cells }\end{array}$ \\
\hline
\end{tabular}


Table 1. Cont.

\begin{tabular}{|c|c|c|}
\hline Seaweed & Active Ingredient(s) & Activity \\
\hline Undaria pinnatifida & Fucoxanthin (25) extracts & Trigger apoptosis in PC-3 cells via caspase- 3 \\
\hline Leathesia nana & Bromo phenol derivatives (18-23) & $\begin{array}{l}\text { Cytotoxicity in various human cancer cells, } \\
\text { including MCF-7A549, BGC823, HCT-8 } \\
\text { cell lines }\end{array}$ \\
\hline $\begin{array}{l}\text { Fucus serratus, luminaria digitat, } \\
\text { ascophyllm nodsum, pelvetia canaliculata }\end{array}$ & Astaxanthin, $\beta$-carotene, zeaxanthin & $\begin{array}{l}\text { Agent for cerebrovascular disease, } \\
\text { photoprotection of eye, and anticancer agent }\end{array}$ \\
\hline Cystoseira abies-marina & $\begin{array}{l}\text { Cystoazorones A (30) and B (31) } \\
\text { cystoazorols A (32) and B }\end{array}$ & Anticancer activity against HeLa cells \\
\hline Dilophus ligulatus & Diterpenoids (33-36 and 37) & $\begin{array}{l}\text { Cytotoxic activity against murine leukemia } \\
\text { cells (p-388) and p-388 doxorubicin-resistant } \\
\text { cells with IC50 3.64-13.3 } \mu \mathrm{M} \text { and } \mathrm{IC}_{50} 5.95 \text { to } \\
12.9 \mu \mathrm{M} \text { respectively }\end{array}$ \\
\hline Stypopodium flabelliforme & Flabellinol (38), flabellinone (39) & $\begin{array}{l}\text { Cytotoxicity against NCI-H460 cells }\left(\mathrm{IC}_{50} 9 \mu \mathrm{M}\right. \\
\text { and } 14 \mu \mathrm{M} \text {, respectively) }\end{array}$ \\
\hline Taonia atomaria & $\begin{array}{l}\text { Atomarianone A (40), atomarianone } \\
\text { B (41) }\end{array}$ & $\begin{array}{l}\text { Cytotoxic activity against two lung cancer cell } \\
\text { lines (NSCLC-N6 and A549) }\end{array}$ \\
\hline Plocamium suhrii & Monoterpenes (44-49) & $\begin{array}{l}\text { Cytotoxic effects toward esophageal cancer cell } \\
\text { lines (WHCO1) with an } \mathrm{IC}_{50} \text { value in the range } \\
6.6-15.1 \mu \mathrm{M}\end{array}$ \\
\hline Stypopodium flabelliforme & 14-keto-stypodiol diacetate (50) & $\begin{array}{l}\text { Cytotoxic effects on the prostate cancer cell line } \\
\text { (DU-145) with } \mathrm{IC}_{50} \text { of } 24 \mu \mathrm{M}\end{array}$ \\
\hline Landsburgia quereifolia & Deoxylapachol (51) & Cytotoxicity to P-388 leukemia cells \\
\hline Perithalia capillaris & Bis-prenylated quinone & $\begin{array}{l}\text { Antiproliferative effects toward HL- } 60 \text { cells } \\
\left(\mathrm{IC}_{50} 0.34 \mathrm{uM}\right)\end{array}$ \\
\hline sargassum siliquastrum & Sargachromanol E (52) & $\begin{array}{l}\text { Growth inhibitory effects against HL- } 60 \text { cells } \\
\text { via caspase- } 3 \text { dependent apoptosis induction }\end{array}$ \\
\hline Cystoseira crinita & Tetraprenyltoluquinols (53) and (54) & $\begin{array}{l}\text { Inhibiting growth of on HMO2, HepG2, and } \\
\text { MCF7 cancer cell lines }\end{array}$ \\
\hline Laurencia tristicha & Cholest-5-en-3b-,7a-diol (55) & $\begin{array}{l}\text { Cytotoxic effects against the tested cancer cell } \\
\text { lines A549, BGC-823, Bel 7402, HCT-8, and } \\
\text { HeLa with } \mathrm{IC}_{50} \text { values of } 16.8 \mu \mathrm{M}, 5.1 \mu \mathrm{M} \text {, } \\
0.5 \mu \mathrm{M}, 0.5 \mu \mathrm{M} \text {, and } 0.3 \mu \mathrm{M} \text {, respectively }\end{array}$ \\
\hline Cystoseira myrica & $\begin{array}{l}\text { 3-Keto-22-epi-28-nor-cathasterone (56), } \\
\text { cholest-4-ene-3,6-dione (57) }\end{array}$ & $\begin{array}{l}\text { Antiproliferative effects to HepG2 and HCT116 } \\
\text { cancer cells }\end{array}$ \\
\hline $\begin{array}{l}\text { Pelvetica siliquosa, Cystoseira } \\
\text { foeniculacea, Sargassum angustifolium }\end{array}$ & Fucosterol (58) & $\begin{array}{l}\text { Cytotoxic effects against various types of } \\
\text { cancer cell lines, including HT- } 29 \text { colon cancer } \\
\text { cells, breast cancer, promyelocytic leukemia, } \\
\text { lung cancer, and cervical cancer }\end{array}$ \\
\hline
\end{tabular}

The numbers enclosed in parentheses indicate compound numbers.

\section{Categories of Bio-Compounds Isolated from Seaweeds with Anticancer Activity}

Seaweeds are marine organisms that produce a variety of bioactive compounds, which are secondary metabolites dependent on environmental conditions, including ultraviolet (UV) light, temperature, nutrient availability, high pressure, salinity, and oxygen content [14].

\section{Seaweed Polysaccharide}

Brown seaweeds are more highly enriched with polysaccharides than other seaweeds, such as yellow and green seaweeds. These polysaccharides from brown seaweeds have attracted great attention owing to their therapeutic effects on cancers. The structures of polysaccharides are shown in Figure 1. Polysaccharides are composed of laminarin (1), al- 
ginate (2), fucoidan (3), and their derivatives. Some species of brown seaweed also contain a small amount of porphyrin (4) [15] and alginic acid (5) derivatives that exhibit anticancer potential and can be utilized as a drug delivery system. Meanwhile, some species of red seaweeds contain carrageenan (6), which contains sulfated polysaccharides, and are used as stabilizers, gelling agents, binders, and additives in the food and pharmaceutical industries [16]. Seaweed polysaccharides possess similar repeating units of carbohydrates with different sulfation and molecular weights. The composition of sulfated polysaccharides and their biological activities are related to different isolation techniques and habituating areas [17]. For instance, fucoidan is a long-chained sulfated polysaccharide that is widely isolated from different seaweed species, such as Undaria pinnatifida, Laminaria japonica, and Fucus vesiculosus [18]. In particular, the dry weight of Sargassum spon. and Focus sp. contained $8 \%$ to $12 \%$ fucoidan polysaccharides. The complex sulfated polysaccharides of fucoidan are also composed primarily of sulfated L-fucose and a small amount of glucose, mannose, xylose, and rhamnose [19].

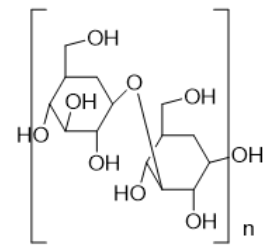

Laminarin (1)

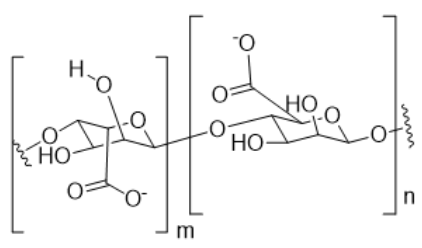

Alginate (2)

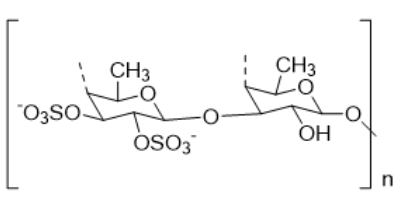

Fucoidan (3)

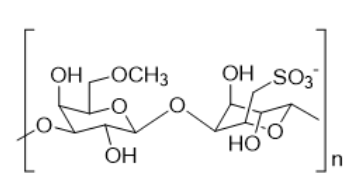

Porphyran (4)

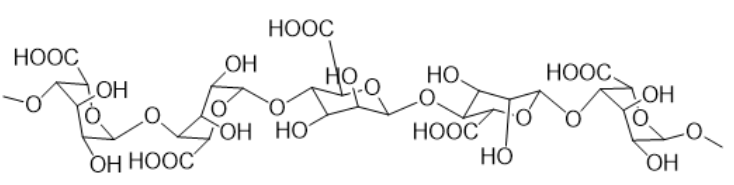

Alginic acid (5)

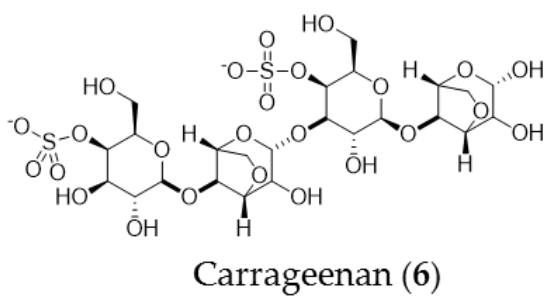

Carrageenan (6)

Figure 1. Structures of seaweed polysaccharides.

Highly sulfated polysaccharide fractions isolated from Sagassum pallidum, specifically SP1, SP2, and SP3, showed potent cytotoxic activity in various cancer cell lines, such as A549 (lung adenocarcinoma), HepG2 (hepatocellular carcinoma), and MGC-803 (gastric cancer) cells [20]. The anticancer activities of the SP fractions correlated with sulfate content. These results indicate that the high sulfate content and lower molecular weight of SP are more advantageous for its anticancer activity. Sulfated polysaccharides isolated from Dictyopteris delicatula and Dictyopteris polyodioides exhibited anticancer activity in HeLa (60-70\%) and RPMI-7951 (28\%) cancer cells [21,22]. The authors investigated the precise mechanisms underlying these anticancer activities, including tumor angiogenesis, modulation of the immune system, arrest of the cell cycle, and apoptosis [23]. Fucoidan (3) isolated from Sargassum hornery, Eclonia cava, and Costaria costata also showed anti-tumor potential, inhibiting colony formation in melanoma (SK-MEL-28 cells) and colon cancer cells (DLD-1 cells) [24]. In this report, it was difficult to correlate the chemical structure of fucoidan (3) and its anticancer activity. Several reports indicate that sulfate content is correlated with anticancer activity [25]; however, their results do not show a correlation between chemical structure and activity. You and colleagues reported that low- and highmolecular-weight fucoidans isolated from the brown seaweed Undaria pinnatifida were structurally modified by adding a sulfate group synthetically.

In stomach AGS cancer cells, the anticancer activity of oversulfated fucoidan was examined. Results showed that a low molecular fraction $(<30 \mathrm{KDa})$ was more potent than the $>30 \mathrm{KDa}$ fraction [26]. Fucoidan, laminarin, and alginate (2) isolated from Coccophora langsdorfii were tested for their anticancer activity against SK-ML-5 and SK-ML-28 melanoma 
cells. The isolated compounds accounted for $28 \%$ and $76 \%$ of these two melanoma cells, respectively. However, the compounds showed weak activity toward breast cancer cells (MDA-MB-231) [27]. To date, polysaccharides and sulfated polysaccharides have been demonstrated to exhibit significant anticancer activity against various in vitro cancer cell models.

Laminarin (1) from the Laminaria difitata showed anticancer effects against ovarian cells by inducing apoptosis signaling and endoplasmic reticulum (ER) stress, reactive oxygen species (ROS) generation, and altering the ER-mitochondria axis [28]. Laminarin (1) also induced apoptosis via the ErbB signaling pathway in colon cancer cells [29]. In addition, ascophyllan extracted from Ascophyllum nodosum inhibited U937 lymphoma growth by inducing DNA fragmentation and eventually apoptosis.

\section{Phenolic Compounds}

Phenolic compounds are a large family of natural organic compounds found in land plants and seaweeds. Polyphenols are known as radical scavengers that improve endogenous antioxidant properties [30,31]. Seaweed polyphenols possess multiple phenolic units. Many seaweeds generate polyphenols as secondary metabolites, and polyphenols have beneficial effects, including antioxidant, antiviral, antimicrobial, and anticancer effects [32,33]. Seaweeds are a valuable source of polyphenolic compounds, such as phlorotannins, bromophenols, flavonoids, phenolic terpenoids, and mycosporine-like amino acids. Various biological activities are related to the interaction of polyphenolic compounds with various cellular receptors, transcription factors, and enzymes [34-36].

Phlorotannins are composed of phloroglucinol (1,3,5-tri-hydroxy benzene) (7) and are found in brown algae, such as kelps, rockweeds, and Sargassacean species, and in red algae in low amounts [37-40]. Phlorotannins are classified into six major groups (Table 2) [41]. Dieckol (14) isolated from the brown algae Ecklonia cava inhibited PANC-1 cell growth by inducing apoptosis. The induction of apoptosis and the expression of apoptotic proteins, such as Bax and Bcl-2, were further analyzed using Western blot [42]. Dieckol (14) also inhibited the proliferation and migration of non-small-cell lung cancer by regulating the PI3K/AKT signaling pathway [43]. Moreover, at a concentration of $84.3 \mu \mathrm{g} / \mathrm{mL}$ and $99.6 \mu \mathrm{g} / \mathrm{mL}$, dieckol (14) inhibited A2780 ovarian carcinoma and SKOV3 cells, respectively [11,44]. The phlorotannin-rich fraction $(100 \mu \mathrm{g} / \mathrm{mL})$ isolated from Laminaria japonica showed 30\% and $43 \%$ inhibitory effects against BEL-7402 human hepatocellular carcinoma cells and P388 murine leukemic cells, respectively [45].

Table 2. Structures of phloroglucinol and six major groups of phlorotannins. Adapted from [41].

\begin{tabular}{|c|c|c|}
\hline Group & Chemical Name & Structure \\
\hline Monomeric unit & Phloroglucinol (7) & \\
\hline Fucol & Trifucol (8) & \\
\hline & & $\mathrm{OH}$ \\
\hline Phlorethol & Tetraphlorethol (9) & \\
\hline
\end{tabular}


Table 2. Cont.

Froup Chemical Name

Carmalol

Diphlorethohydroxycarmalol (12)<smiles>Oc1cc(O)cc(Oc2c(O)cc3c(c2O)Oc2cc(Oc4c(O)cc(O)cc4O)c(O)c(O)c2O3)c1</smiles>

Eckol (13)<smiles>Oc1cc(O)cc(Oc2c(O)cc(O)c3c2Oc2c(O)cc(O)cc2O3)c1</smiles>

Eckols
Dieckol (14)

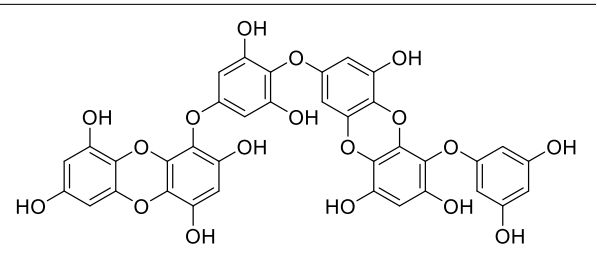

The numbers enclosed in parentheses indicate compound numbers.

Figure 2 shows structures of phenolic compounds. The 8,8-bieckol (15), 6,6-bieckol (16), and 6,8-bieckol (17) have been isolated from several brown algae; however, their anticancer activities have not yet been reported. Phloroglucinol isolated from Ecklonia cava decreased the cell viability of and induced apoptosis in HT-29 cells by altering Bcl-2 family proteins, cytochrome c release, and activation of caspase-3 and caspase-8 [46]. Furthermore, phloroglucinol decreased CD44 (+) cancer cells and cancer stem cell regulators, including sox2, CD44, Oct4, Notch2, and $\beta$-catenin [47]. Furthermore, phloroglucinol increased the sensitivity of breast cancer cells to anticancer drugs, such as cisplatin, doxorubicin, and taxol. Phloroglucinol regulates the maintenance of breast cancer stem-like cells (BCSCs) by inhibiting Kirsten rat sarcoma virus (KRAS) and its downstream regulators of the PI3K/AKT and RAF-1/ERK signaling pathway [47]. 


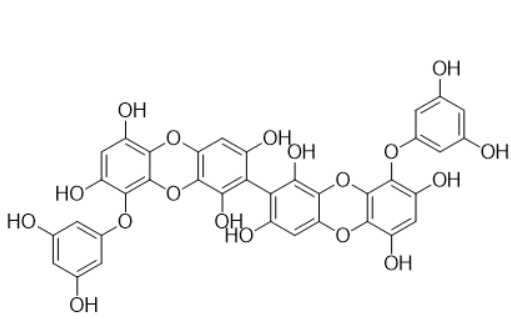

8,8'-Bieckol(15)

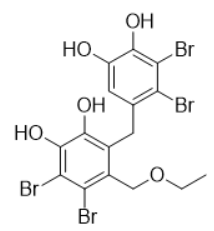

bromophenol 1 (18)

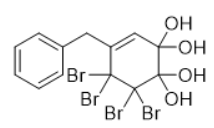

bromophenol 4 (21)
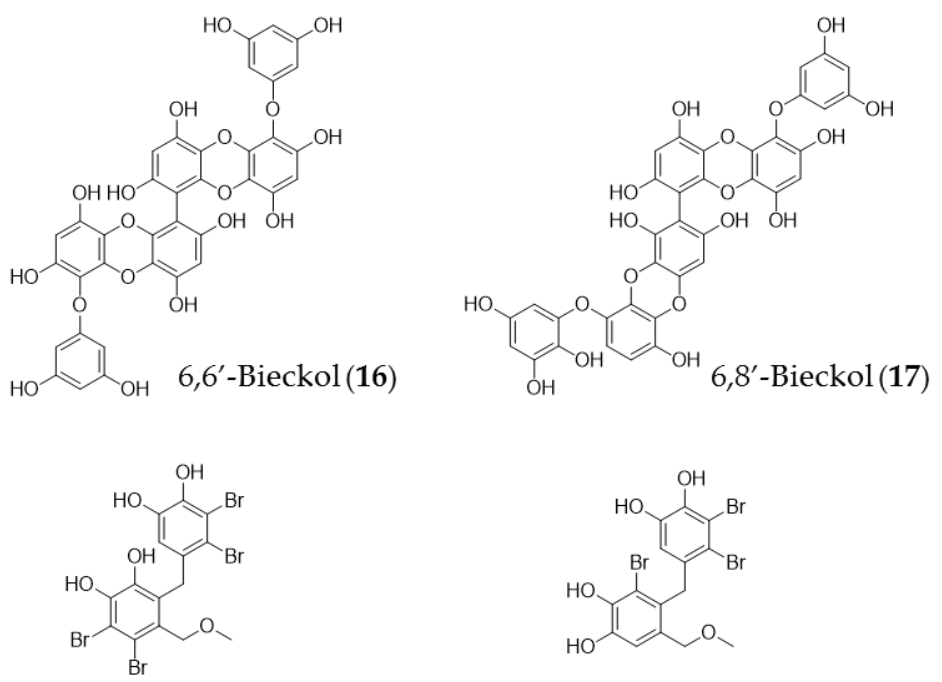

bromophenol 2 (19)

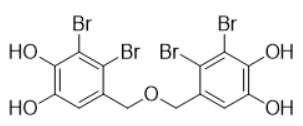

bromophenol 5 (22)

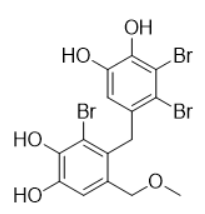

bromophenol 3 (20)

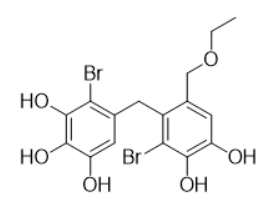

bromophenol 6 (23)

Figure 2. Structures of phenolic compounds, including phlorotannins and bromophenols.

Bromophenol (BP) compounds are secondary metabolites of marine algae, which have benzene rings attached to substituents, such as hydroxyl and bromine. Many studies have demonstrated the anti-tumor properties of marine BP by using different in vitro and in vivo tumor models. BP derivatives (18-23), with the 2,3-dibromo-4,5-dihydroxy benzoyl unit, derived from the brown algae Leathesia nana, showed cytotoxicity in various human cancer cells including MCF-7A549, BGC823, and HCT-8 cell lines [11,48-50].

\section{Carotenoids}

Carotenoids are lipid-soluble organic compounds pigmented with yellow, orange, and red colors. Carotenoids exert diverse beneficial functions, including the reduction of oxidative stress on the retina [51]. They are synthesized by photosynthetic microorganisms (cyanobacteria, algae, plants), as well as by some fungi and bacteria [52]. In particular, algal carotenoids have various unique structures, such as $\alpha$-carotene, $\beta$-carotene, chlorophyll, lutein, zeaxanthin, and fucoxanthin. These carotenoids play an important role in human health by providing pro-vitamin $\mathrm{A}$, as well as acting as agents for cerebrovascular disease, photoprotection, and anticancer agents.

However, animals are unable to synthesize carotenoids endogenously. Animals obtain carotenoids from their diet and modify their structures [53]. Approximately 30 types of carotenoids are found in the algae. Some of these were found in particular algal groups. Figure 3 shows example of seaweed carotenoids. For instance, the unique allene $(C=C=C)$ structure is present in natural products and has been discovered in dinoxanthin (24), fucoxanthin (25), peridinin (26), and pyrrhoxanthin (27) [11,54,55]. Another unique acetylene $(\mathrm{C} \equiv \mathrm{C})$, commonly found in alloxanthin diterpenoids, monads, dinoxanthin (24), and crocoxanthin (29), was isolated from a variety of alagal species, such as Cryptophyta, Haptophyta, Dinophyta, and Euglenophyta. Meanwhile, fucoxanthin (25), peridinin (26), and pyrrhoxanthin (27) have an acetylated group $\left(-\mathrm{O}-\mathrm{CO}-\mathrm{CH}_{3}\right)$ at the hydroxyl position, which is mainly found in Heterokontophyta, Dinophyta, and Haptophyta [11,56-59]. Among these seaweed carotenoids, fucoxanthin (25) and its deacetylated metabolite fucoxanthinol are known for their anticancer potential. 


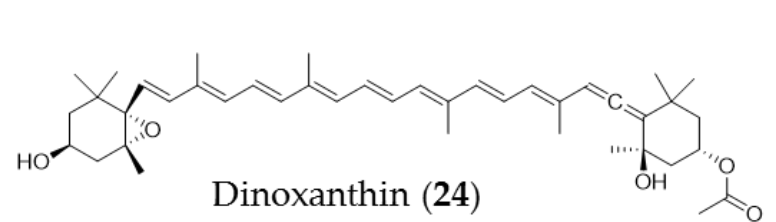

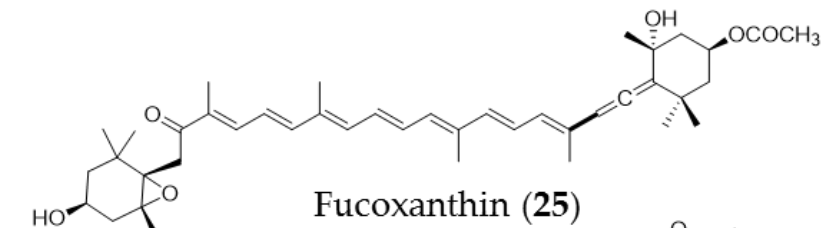<smiles>COC(=O)C1CC(O)CC(C)C1C=CC(C)=CC=CC=CC=C(C)C=C1C=C(C=CC2(C)CC(O)CC2C)C(=O)O1</smiles>

Peridinin (26)<smiles>CC(C)=CC=CC(C)=CC=CC=CC(C)=CC=CC(C)=CC=CC(C)=C1CC(O)CC(C)=C1C</smiles>

Alloxanthin (28)

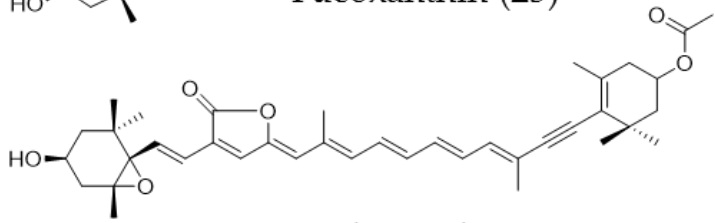

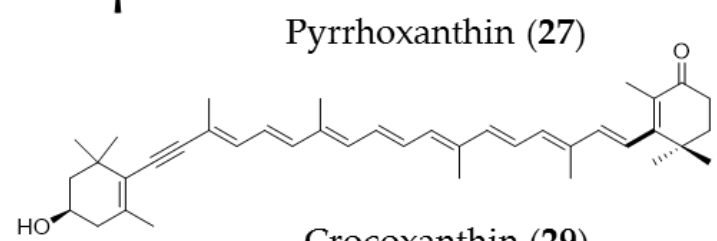

Crocoxanthin (29)

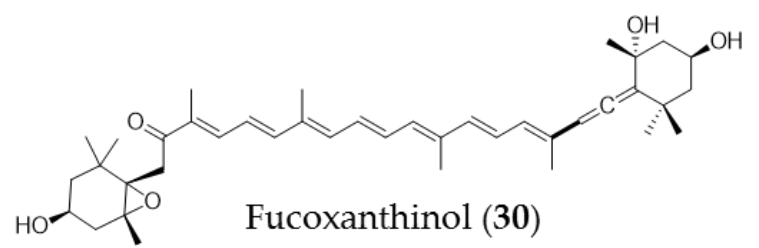

Figure 3. Structures of seaweed carotenoids.

In particular, fucoxanthin (25) induced apoptosis by modulating various signaling pathways, including downregulation of mitogen-activated protein kinase and B-cell lymphoma 2 (Bcl-2), and activating the poly (ADP-ribose) polymerase (PARP) and caspase$3,-8,-9$ [60]. Moreover, fucoxanthin decreased cancer cell metastasis by downregulating the mRNA expression levels of CD44 and CXCR4 and diminished the level of matrix metallopeptidase 9 [61]. Fucoxanthin also induced cell cycle arrest by decreasing the expression levels of cyclin D1, cyclin D2, cyclin-dependent kinase 4 (CDK4), CDK6, and cIAP2 [62,63]. Fucoxanthin (25) and fucoxanthiol (30) reduced the proliferation of human umbilical vein endothelial cells. Likewise, brown algae fucoxanthin extracts triggered the apoptosis in PC-3 cells via caspase-3 and enhanced the density of hypodiploid cells [64]. Furthermore, BCL2-associated X, apoptosis regulator (Bax), and Bcl-2 apoptosis-associated protein levels, except $\mathrm{Bc}-\mathrm{XL}$, were downregulated by fucoxanthin (25) [65]. The macroalgae and microalgae fucoxanthin attenuated cell growth and triggered cell death pathways in diverse cancer cell lines and in vivo models. In addition, it prevents the transition, spread, and invasion of tumor metastasis [66].

\section{Mono-, Sesqui-, and Diterpenes}

Terpenoids have been shown to inhibit the growth of a variety of cancer cells, including leukemia, breast cancer, prostate cancer, pancreatic cancer, skin cancer, and colon cancers [67-69]. For more than two decades, several terpenes from seaweeds have been investigated as anticancer compounds with relevant cytotoxic activities against various cancer cell lines. Figure 4 shows examples of seaweed terpenoids. The cytotoxicity of meronorsesquiterpenes (cystoazorones A [30] and B [31]) and two new meroditerpenes (cystoazorol A and B) isolated from Cystoseira abies-marina were evaluated in HeLa cells. Cystoazorol A (32) was three times more potent than cystoazorone A when comparing the $\mathrm{IC}_{50}$ value [70].

The diterpenoids (33-36 and 37) isolated from the Mediterranean brown algae Dilophus ligulatus showed interesting cytotoxic activity against murine leukemia cells ( $\mathrm{p}-388$ ) and p-388 doxorubicin-resistant cells with IC50 3.64-13.3 $\mu \mathrm{M}$ and $\mathrm{IC}_{50} 5.95-12.9 \mu \mathrm{M}$, respectively [71]. Flabellinol (38) and flabellinone (39) isolated from S. flabelliforme possessed 
two polycyclic fused oxidized rings that exhibited cytotoxicity against NCI-H460 cells ( $\mathrm{IC}_{50}$ $9 \mu \mathrm{M}$ and $14 \mu \mathrm{M}$, respectively) by blocking the cellular sodium channel activity [72]. Two cyclic meroditerpenoids, atomarianone A (40) and atomarianone B (41), which are analogs of flabellinone (39), were isolated from the brown algae Taonia atomaria in the Aegean Sea. This previous study is the second report on metabolites with a functionalized indane moiety instead of a benzofurano- or a benzopyrano-ring connecting their aromatic and diterpenoid parts. Both metabolites exhibited significant cytotoxic activity against two lung cancer cell lines (NSCLC-N6 and A549) [73].
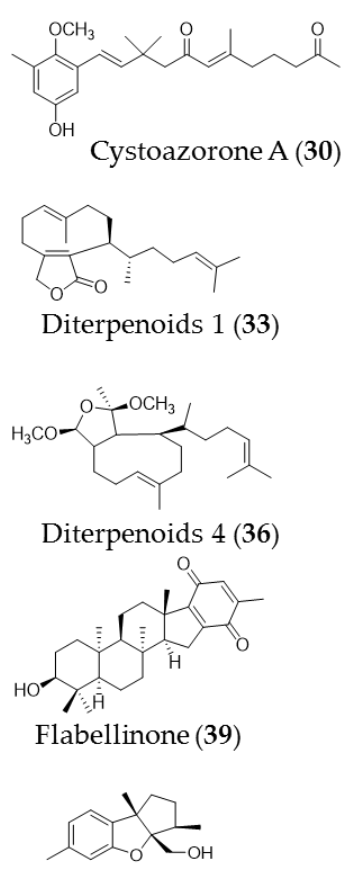

debromoepiaplysinol (43)

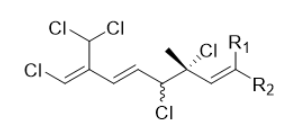

$\mathrm{R}_{1}=\mathrm{H}, \mathrm{R}_{2}=\mathrm{Br}(4 \mathrm{~S})$ (47)

$\mathrm{R}_{1}=\mathrm{H}, \mathrm{R}_{2}=\mathrm{Br}(4 \mathrm{R})(48)$

$\mathrm{R}_{1}=\mathrm{Br}, \mathrm{R}_{2}=\mathrm{H}$ (4S) (49)

$\mathrm{R}_{1}=\mathrm{R}_{2}=\mathrm{H}(4 \mathrm{~S})$
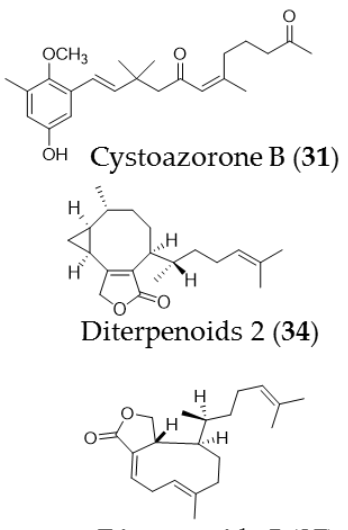

Diterpenoids 5 (37)

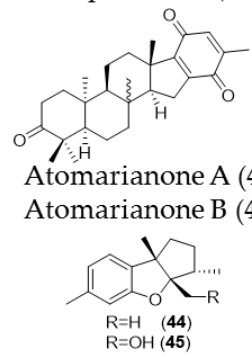

debromoaplysin (44)

debromoaplysinol (45)<smiles>C=CC(C)(Cl)CC(Cl)C(C)(C)Cl</smiles>

(51)

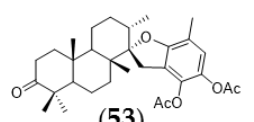

(53)

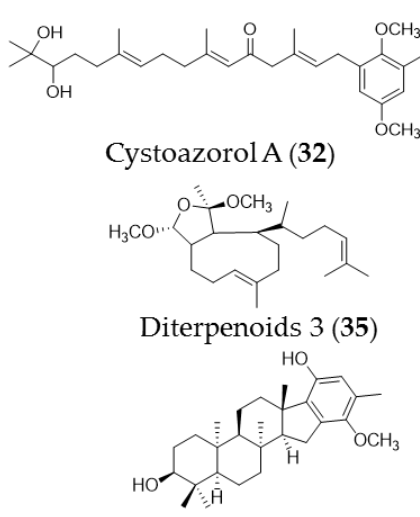

Flabellinol (38)

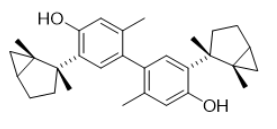

Laurebiphenyl (42)

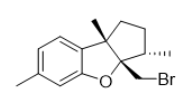

isoaplysin (46)

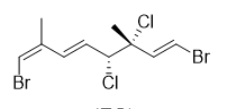

(52)

Figure 4. Chemical structures of terpenoids isolated from seaweeds.

Red algae of the genus Laurencia in tropical oceans are known to have highly diverse secondary metabolites, especially terpenoids and acetogenins $[74,75]$. Some of these metabolites, including laurebiphenyl (42), debromoepiaplysinol (43), debromoaplysin (44), and isoaplysin (46), exhibited cytotoxic effects against various types of cancer cell lines [76,77]. In particular, debromoaplysinol (45) and isoaplysin (46) are sesquiterpenes with different structures, with C3a-hydroxyl and C3a-bromomethyl groups. Debromoaplysin (44) showed more selective toxicity to cancer cell lines than isoaplysin (46) [77]. Meanwhile, debromoepiaplysinol (43) and debromoaplysinol (45) are epimers because of the difference in the stereochemistry at the $\mathrm{C} 3$ chiral center. The chiral center plays a pivotal role in the drug-receptor interaction. Therefore, debromoepiaplysinol (43) is less active than debromoaplysin (44).

The monoterpenes (47-52) isolated from the macroalga Plocamium suhrii collected from South Africa were identified as halogenated compounds. The halogenated monoterpenes showed strong cytotoxic effects on esophageal cancer cell lines (WHCO1) with an $\mathrm{IC}_{50}$ value in the range of 6.6-15.1 $\mu \mathrm{M}[78]$. 
The seaweed diterpenoid 14-keto-stypodiol diacetate (53), isolated from Stypopodium flabelliforme, showed cytotoxic effects on the prostate cancer cell line DU-145 with an $\mathrm{IC}_{50}$ of $24 \mu \mathrm{M}$. This compound exhibited a clear mechanism of microtubule assembly inhibition, which can cause mitotic arrest and inhibitory effects on cell invasion [79]. However, the molecular mechanisms of many marine natural products are not clear because of their lower activity.

\section{Other Compounds (Quinones and Sterols)}

Figure 5 shows structures of quinones and sterols isolated from seaweeds. Deoxylapachol (54) and 1,4-naphthoquione derivatives isolated from Landsburgia quereifolia demonstrated cytotoxicity against P-388 leukemia cells [80]. Bis-prenylated quinon, extracted from the brown alga Perithalia capillaris, showed antiproliferative effects against HL-60 cells $\left(\mathrm{IC}_{50} 0.34 \mathrm{uM}\right.$ ) [81]. Sargachromanol E (55), obtained from Sargassum siliquastrum, inhibited growth of HL-60 cells via caspase-3 dependent apoptosis induction. These results indicate that DNA fragmentation leads to the accumulation of cells in the sub-G1 phase. Furthermore, sargachromanol E reduced Bcl-xL expression and enhanced Bax expression [82]. Tetraprenyltoluquinols (56) and (57) were found in Cystoseira crinita brown algae [83,84]. The compounds successfully inhibited the growth of HMO2, HepG2, and MCF7 cancer cell lines by inducing cell death [83].

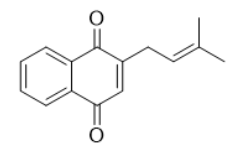

Deoxylapachol (54)

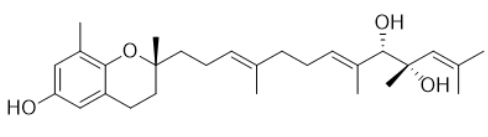

Sargachromanol E (55)

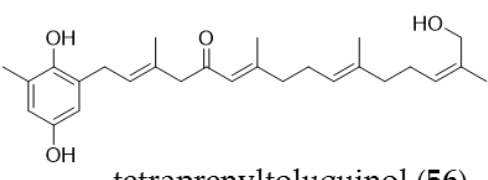

tetraprenyltoluquinol (56)<smiles>CC(C)=CC(=O)CC(C)=CCC=C(C)CCC=C(C)CCCC(C)=CCc1cc(C)cc(C)c1O</smiles>

tetraprenyltoluquinol (57) Cholest-5-en-3b-,7a-diol(58)

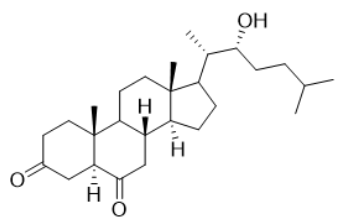

3-keto-22-epi-28-nor-cathasterone (59)

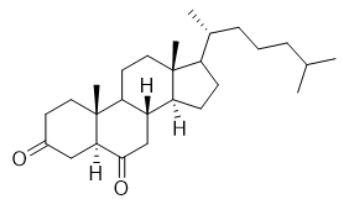

Cholest-4-ene-3,6-dione (60)

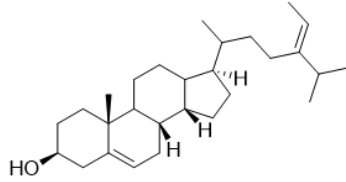

Fucosterol(61)

Figure 5. Chemical structures of quinones and sterols isolated from seaweeds.

Cholest-5-en-3 $\beta-, 7 \alpha$-diol (58), purified from the red algae Laurencia tristicha, exhibited cytotoxic effects against A549, BGC-823, Bel 7402, HCT-8, and HeLa cancer cell lines with $\mathrm{IC}_{50}$ values of $16.8 \mu \mathrm{M}, 5.1 \mu \mathrm{M}, 0.5 \mu \mathrm{M}, 0.5 \mu \mathrm{M}$, and $0.3 \mu \mathrm{M}$, respectively [13,76]. Meanwhile, 3-keto-22-epi-28-nor-cathasterone (59) and cholest-4-ene-3,6-dione (60), a brassinosteroidrelated metabolite purified from the brown algae Cystoseira myrica, showed antiproliferative effects against HepG2 and HCT116 cancer cells [85]. Fucosterol (61) isolated from Pelvetica siliquosa, Cystoseira foeniculacea, and Sargassum angustifolium exhibited cytotoxic effects against various types of cancer cell lines, including HT-29 colon cancer cells [86], breast cancer [87,88], promyelocytic leukemia [86], lung cancer [89], and cervical cancer [90]. Furthermore, fucosterol treatment suppressed the growth of ES2 and OV90 human ovarian cancer cell lines by inducing mitochondrial dysfunction and endoplasmic reticulum stress [91]. 


\section{Conclusions}

Over the past few decades, various anticancer studies have been performed using natural extracts or natural products obtained from seaweeds to discover novel anticancer compounds with greater efficacy and specificity and fewer side effects. Among the natural products obtained from these seaweeds, several compounds with therapeutic potential are able to induce cancer cell death through various signaling pathways, including apoptosis, arrest of the cell cycle, decrease in Bcl-2 expression, and induction of anti-metastasis by inhibiting MMP activity. Furthermore, several compounds from marine seaweed inhibited angiogenesis by antagonizing the interaction of VEGF with its receptor [92]. For example, fucoidan decreased the viability of various cancer cells via cell cycle arrest in the G1 phase and induced p53-independent apoptosis [93]. This review described the anticancer activities and molecular mechanisms underlying the activities of natural seaweed products against various cancers.

Author Contributions: Conceptualization, H.L. and J.W.L.; methodology, J.W.L.; investigation, J.W.L.; writing-original draft preparation, H.L. and J.W.L.; writing—review and editing, B.S. and J.W.L.; visualization, J.W.L.; funding acquisition, J.W.L. All authors have read and agreed to the published version of the manuscript.

Funding: This research was funded by National Research Foundation of Korea, grant number NRF-2019K1A3A1A82113697, KIST Institutional Program, grant number 2Z06603, 2Z06481, and the National Research Council of Science and Technology (NST), grant number CRC-15-04-KIST.

Institutional Review Board Statement: Not applicable.

Informed Consent Statement: Not applicable.

Data Availability Statement: Not applicable.

Conflicts of Interest: The authors declare no conflict of interest.

\section{References}

1. Weinberg, R. The Biology of Cancer, Garland Science, 2nd ed.; W.W.Norton \& Company: New York, NY, USA, 2013.

2. Curtius, K.; Wright, N.A.; Graham, T.A. An evolutionary perspective on cancerization. Nat. Rev. Cancer 2018, 18, 19-32. [CrossRef]

3. American Cancer Society. What Is Cancer? American Cancer Society: Atlanta, GA, USA, 2020; Available online: https://www. cancer.org/cancer/cancer-basics / what-is-cancer.html (accessed on 30 October 2021).

4. Chakravarthi, B.V.S.K.; Nepal, S.; Varambally, S. Genomic and epigenomic alterations in cancer. Am. J. Pathol. 2016, 186, 1724-1735. [CrossRef]

5. Atashrazm, F.; Lowenthal, R.M.; Woods, G.M.; Holloway, A.F.; Dickinson, J.L. Fucoidan and Cancer: A Multifunctional Molecule with Anti-Tumor Potential. Mar. Drugs 2015, 13, 2327-2346. [CrossRef]

6. American Cancer Society. Cancer Facts \& Figures 2021. Available online: https://www.cancer.org/research/cancer-facts-statistics / all-cancer-facts-figures / cancer-facts-figures-2021.html (accessed on 30 October 2021).

7. Hoadley, K.A.; Yau, C.; Hinoue, T.; Wolf, D.M.; Lazar, A.J.; Drill, E.; Shen, R.; Taylor, A.M.; Cherniack, A.D.; Thorsson, V.; et al. Cell-of-origin patterns dominate the molecular classification of 10,000 tumors from 33 types of cancer. Cell 2018, 173, 291-304. [CrossRef] [PubMed]

8. Moussavou, G.; Kwak, D.H.; Obiang-Obonou, B.W.; Maranguy, C.A.O.; Dinzouna-Boutamba, S.-D.; Lee, D.H.; Pissibanganga, O.G.M.; Ko, K.; Seo, J.I.; Choo, Y.K. Anticancer effects of different seaweeds on human colon and breast cancers. Mar. Drugs 2014, 12, 4898-4911. [CrossRef] [PubMed]

9. Jin, J.O.; Zhang, W.; Du, J.Y.; Wong, K.W.; Oda, T.; Yu, Q. Fucoidan can function as an adjuvant in vivo to enhance dendritic cell maturation and function and promote antigen-specific $t$ cell immune responses. PLoS ONE 2014, 9, e99396.

10. Ganesan, A.R.; Tiwari, U.; Rajauria, G. Seaweed nutraceuticals and their therapeutic role in disease prevention. Food Sci. Hum. Wellness 2019, 8, 252-263. [CrossRef]

11. Hussain, E.; Wang, L.J.; Jiang, B.; Riaz, S.; Butt, G.Y.; Shi, D.-Y. A review of the components of brown seaweeds as potential candidates in cancer therapy. RSC Adv. 2016, 6, 12592. [CrossRef]

12. Gutierrez-Rodriguez, A.G.; Juarez-Portilla, C.; Olivares-Banuelos, T.; Zepeda, R.C. Anticancer activity of seaweeds. Drug Discov. Today 2018, 23, 434-447. [CrossRef]

13. Rocha, D.H.A.; Seca, A.M.L.; Pinto, D.C.G. Seaweed secondary metabolites in vitro and in vivo anticancer activity. Mar. Drugs 2018, 16, 410. [CrossRef]

14. Winter, C.; Bouvier, T.; Weinbauer, M.G.; Thingstad, T.F. Trade-offs between competition and defense specialists among unicellular planktonic organisms: The "killing tShe winner" hypothesis revisited. Microbiol. Mol. Biol. Rev. 2010, 74, 42-57. [CrossRef] 
15. Liu, Z.; Gao, T.; Yang, Y.; Meng, F.; Zhan, F.; Jiang, Q.; Sun, X. Anti-cancer activity of porphyran and carrageenan from red seaweeds. Molecules 2019, 24, 4286. [CrossRef]

16. Prasedya, E.S.; Miyake, M.; Kobayashi, D.; Hazama, A. Carrageenan delays cell cycle progression in human cancer cells in vitro demonstrated by FUCCI imaging. BMC Complement. Altern. Med. 2016, 16, 270. [CrossRef] [PubMed]

17. Funaki, M.M.; Nishizawa, M.; Sawaya, V.; Inoue, S.; Yamagishi, V. Mineral composition in the holdfast of three brown algae of the genus Laminaria. Fish. Sci. 2001, 67, 295. [CrossRef]

18. Fitton, J.H. Therapies from fucoidan; multifunctional marine polymers. Mar. Drugs 2011, 9, 1731-1760. [CrossRef] [PubMed]

19. Gamal-Eldeen, A.M.; Ahmed, E.F.; Abo-Zeid, M.A. In vitro cancer chemopreventive properties of polysaccharide extract from the brown alga, Sargassum latifolium. Food Chem. Toxicol. 2009, 47, 1378.

20. Ye, H.; Wang, K.; Zhou, C.; Liu, J.; Zeng, X. Purification, antitumor and antioxidant activities in vitro of polysaccharides from the brown seaweed Sargassum pallidum. Food Chem. 2008, 111, 428. [CrossRef]

21. Magalhaes, K.D.; Costa, L.S.; Fidelis, G.P.; Oliveira, R.M.; Nobre, L.T.D.B.; Dantas-Santos, N.; Camara, R.B.G.; Albuquerque, I.R.L.; Cordeiro, S.L.; Sabry, D.A. Anticoagulant, antioxidant and antitumor activities of heterofucans from the seaweed Dictyopteris delicatula. Int. J. Mol. Sci. 2011, 12, 3352-3365. [CrossRef]

22. Sokolova, R.; Ermakova, S.; Awada, S.; Zvyagintseva, T.; Kanaan, H. Composition, structural characteristics, and antitumor properties of polysaccharides from the brown algae Dictyopteris polypodioides and Sargassum sp. Chem. Nat. Compd. 2011, 47, 329. [CrossRef]

23. Ye, J.; Li, Y.; Teruya, K.; Katakura, Y.; Ichikawa, A.; Eto, H.; Hosoi, M.; Hosoi, M.; Nishimoto, S.; Shirahata, S. Enzyme-digested fucoidan extracts derived from seaweed mozuku of cladosiphon novae-caledoniae kylin inhibit invasion and angiogenesis of tumor cells. Cytotechnology 2005, 47, 117-126. [CrossRef] [PubMed]

24. Ermakova, S.; Sokolova, R.; Kim, S.-M.; Um, B.-H.; Isakov, V.; Zvyagintseva, T. Fucoidans from brown seaweeds Sargassum hornery, Eclonia cava, Costaria costata: Structural characteristics and anticancer activity. Appl. Biochem. Biotechnol. 2011, $164,841$. [CrossRef]

25. Alekseyenko, T.V.; Zhanayeva, Y.S.; Venediktova, A.A.; Zvyagintseva, T.N.; Kuznetsova, T.A.; Besednova, N.N.; Korolenko, T.A. Antitumor and antimetastatic activity of fucoidan, a sulfated polysaccharide isolated from the Okhotsk sea Fucus evanescens brown alga. Bull. Exp. Biol. Med. 2007, 143, 730-732. [CrossRef]

26. Cho, M.L.; Lee, B.-Y.; You, S.G. Relationship between oversulfation and conformation of low and high molecular weight fucoidans and evaluation of their in vitro anticancer activity. Molecules 2010, 16, 291. [CrossRef] [PubMed]

27. Imbs, T.I.; Ermakova, S.P.; Malyarenko, O.S.; Isakov, V.V.; Zvyagintseva, T.N. Structural elucidation of polysaccharide fractions from the brown alga Coccophora langsdorfii and in vitro investigation of their anticanceractivity. Carbohydr. Polym. 2016, 135, 162-168. [CrossRef] [PubMed]

28. Bae, H.; Song, G.; Lee, J.-Y.; Hong, T.; Chang, M.-J.; Lim, W. Laminarin-derived from brown algae suppresses the growth of ovarian cancer cells via mitochondrial dysfunction and ER stress. Mar. Drugs 2020, 18, 152. [CrossRef] [PubMed]

29. Park, H.-K.; Kim, I.-H.; Kim, J.; Nam, T.-J. Induction of apoptosis and the regulation of ErbB signaling by laminarin in HT-29 human colon cancer cells. Int. J. Mol. Med. 2013, 32, 291. [CrossRef]

30. Corsetto, P.A.; Montorfano, G.; Zava, S.; Colombo, I.; Ingadottir, B.; Jonsdottir, R.; Sveinsdottir, K.; Maria Rizzo, A. Characterization of antioxidant potential of seaweed extracts for enrichment of convenience food. Antioxidants 2020, 9, 249. [CrossRef]

31. Cotas, J.; Leandro, A.; Monteiro, P.; Pacheco, D.; Figueirinha, A.; Gonçalves, A.M.M.; da Silva, G.J.; Pereira, L. Seaweed phenolics: From extraction to applications. Mar. Drugs 2020, 18, 348. [CrossRef]

32. Besednova, N.N.; Andryukov, B.G.; Zaporozhets, T.S.; Kryzhanovsky, S.P.; Fedyanina, L.N.; Kuznetsova, T.A.; Zuyagintseva, T.N.; Shchelkanov, M.Y. Antiviral effects of polyphenols from marine algae. Biomedicine 2021, 9, 200. [CrossRef]

33. Rosa, G.P.; Tavares, W.R.; Sousa, P.M.C.; Pagès, A.K.; Seca, A.M.L.; Pinto, D.C.G.A. Seaweed secondary metabolites with beneficial health effects: An overview of successes in in vivo studies and clinical trials. Mar. Drugs 2020, 18, 8. [CrossRef]

34. Amsler, C.D.; Fairhead, V.A. Defensive and sensory chemical ecology of brown algae. Adv. Bot. Res 2005, 43, 1-91.

35. Alfadda, A.A.; Sallam, R.M. Reactive oxygen species in health and disease. J. Biomed. Biotechnol. 2012, 2012, 936486. [CrossRef] [PubMed]

36. Schultz, J.C.; Hunter, M.D.; Appel, H.M. Antimicrobial activity of polyphenols mediates plant-herbivore interactions. In Plant Polyphenols; Hemingway, R.W., Laks, P.E., Eds.; Springer: Boston, MA, USA, 1992; pp. 621-637.

37. Koivikko, R.; Loponen, J.; Pihlaja, K.; Jormalainen, V. High-performance liquid chromatographic analysis of phlorotannins from the brown alga Fucus Vesiculosus. Phytochem. Anal. 2007, 18, 326-332. [CrossRef]

38. Jormalainen, V.; Honkanen, T. Variation in natural selection for growth and phlorotannins in the brown alga Fucus vesiculosus. J. Evol. Biol. 2004, 17, 807-820. [CrossRef]

39. Wang, T.; Jónsdóttir, R.; Ólafsdóttir, G. Total phenolic compounds, radical scavenging and metal chelation of extracts from Icelandic seaweeds. Food Chem. 2009, 116, 240-248. [CrossRef]

40. Liu, H.; Gu, L. Phlorotannins from Brown Algae (Fucus vesiculosus) Inhibited the formation of advanced glycation endproducts by scavenging reactive carbonyls. J. Arg. Food Chem. 2012, 60, 1326-1334. [CrossRef]

41. Erpel, F.; Mateos, R.; Pérez-Jiménez, J.; Pérez-Correa, J.R. Phlorotannins: From isolation and structural characterization, to the evaluation of their antidiabetic and anticancer potential. Food Res. Int. 2020, 137, 109589. [CrossRef] 
42. Xu, J.W.; Yan, Y.; Wang, L.; Wu, D.; Ye, N.K.; Chen, S.H.; Li, F. Marine bioactive compound dieckol induces apoptosis and inhibits the growth of human pancreatic cancer cells PANC-1. J. Biochem. Mol. Toxicol. 2021, 35, 22648. [CrossRef]

43. Wang, C.-H.; Li, X.-F.; Jin, L.-F.; Zhao, Y.; Zhu, G.-J.; Shen, W.-Z. Dieckol inhibits non-small-cell lung cancer cell proliferation and migration by regulating the PI3K/AKT signaling pathway. J. Biochem. Mol. Toxicol. 2019, 33, e22346. [CrossRef]

44. Ahn, J.-H.; Yang, Y.-I.; Lee, K.-T.; Choi, J.-H. Dieckol, isolated from the edible brown algae Ecklonia cava, induces apoptosis of ovarian cancer cells and inhibits tumor xenograft growth. J. Cancer Res. Clin. Oncol. 2015, 141, 255-268. [CrossRef] [PubMed]

45. Yang, H.; Zeng, M.; Dong, S.; Liu, Z.; Li, R. Anti-proliferative activity of phlorotannin extracts from brown algae Laminaria japonica Aresch. Chin. J. Oceanol. Limnol. 2010, 28, 122-130. [CrossRef]

46. Kang, M.-H.; Kim, I.-H.; Nam, T.-J. Phloroglucinol induces apoptosis via apoptotic signaling pathways in HT-29 colon cancer cells. Oncol. Rep. 2014, 32, 1341-1346. [CrossRef]

47. Kim, R.-K.; Uddin, N.; Hyun, J.-W.; Kim, C.; Suh, Y.; Lee, S.-J. Novel anticancer activity of phloroglucinol against breast cancer stem-like cells. Toxicol. Appl. Pharmacol. 2015, 286, 143-150. [CrossRef]

48. Liu, M.; Hansen, P.E.; Lin, X. Bromophenols in marine algae and their bioactivities. Mar. Drugs 2011, 9, 1273-1292. [CrossRef]

49. Xu, X.; Song, F.; Wang, S.; Li, S.; Xiao, F.; Zhao, J.; Yang, Y.; Shang, S.; Yang, L.; Shi, J. Dibenzyl bromophenols with diverse dimerization patterns from the brown alga Leathesia nana. J. Nat. Prod. 2004, 67, 1661-1666. [CrossRef] [PubMed]

50. Shi, D.; Li, J.; Guo, S.; Su, H.; Fan, X. The antitumor effect of bromophenol derivatives in vitro and Leathesia nana extract in vivo. Chin. J. Oceanol. Limn. 2009, 27, 277-282. [CrossRef]

51. Ngamwonglumlert, L.; Devahastin, S. Encyclopedia of Food Chemistry; Elsevier: Amsterdam, The Netherlands, 2019.

52. Meléndez-Martínez, A.J.; Mandić, A.I.; Bantis, F.; Böhm, V.; Borge, G.I.A.; Brnčić, M.; Bysted, A.; Cano, M.P.; Dias, M.G.; Elgersma, A.; et al. A comprehensive review on carotenoids in foods and feeds: Status quo, applications, patents, and research needs. Crit. Rev. Food Sci. Nutr. 2021, 1-51. [CrossRef] [PubMed]

53. Rodriguez-Concepcion, M.; Avalos, J.; Bonet, M.L.; Boronat, A.; Gomez-Gomez, L.; Hornero-Mendez, D.; Limon, M.C.; MelendezMartınez, A.J.; Olmedilla-Alonso, B.; Palou, A.; et al. A global perspective on carotenoids: Metabolism, biotechnology, and benefits for nutrition and health. Prog. Lipid. Res. 2018, 70, 62-93. [CrossRef]

54. Takaichi, S. Carotenoids in algae: Distributions, biosyntheses and functions Mar. Drugs 2011, 9, 1101-1118. [CrossRef]

55. Dembitsky, V.M.; Maoka, T. Allenic and cumulenic lipids. Prog. Lipid. Res. 2007, 46, 328-375. [CrossRef]

56. Takaichi, S.; Mimuro, M. Distribution and geometric isomerism of neoxanthin in oxygenic phototrophs: $9^{\prime}$-cis, a sole molecular form. Plant Cell Physiol. 1998, 39, 968-977. [CrossRef]

57. Yoshii, Y.; Takaichi, S.; Maoka, T.; Suda, S.; Sekiguchi, H.; Nakayama, T.; Inouye, I. Variation of siphonaxanthin series among the genus Nephroselmis (Prasinophyceae, Chlorophyta), including a novel primary methoxy carotenoid. J. Phycol. 2005, 41, 827-834. [CrossRef]

58. Takaichi, S.; Mochimaru, M. Carotenoids and carotenogenesis in cyanobacteria: Unique ketocarotenoids and carotenoid glycosides. Cell. Mol. Life Sci. 2007, 64, 2607-2619. [CrossRef] [PubMed]

59. Takaichi, S.; Nippon Medical School, Kawasaki, Japan. Unpublished works. 2011.

60. Kotake-Nara, E.; Terasaki, M.; Nagao, A. Characterization of apoptosis induced by fucoxanthin in human promyelocytic leukemia cells. Biosci. Biotechnol. Biochem. 2005, 69, 224-227. [CrossRef] [PubMed]

61. Chung, T.W.; Choi, H.-J.; Lee, J.-Y.; Jeong, H.-S.; Kim, C.-H.; Joo, M.; Choi, J.-Y.; Han, C.-W.; Kim, S.-Y.; Choi, J.-S.; et al. Marine algal fucoxanthin inhibits the metastatic potential of cancer cells. Biochem. Biophys. Res. Commun. 2013, 439, 580-585. [CrossRef]

62. Kim, K.-N.; Ahn, G.; Heo, S.-J.; Kang, S.-M.; Kang, M.-C.; Yang, H.-M.; Kim, D.; Roh, S.W.; Kim, S.-K.; Jeon, B.-T.; et al. Inhibition of tumor growth in vitro and in vivo by fucoxanthin against melanoma B16F10 cells. Environ. Toxicol. Pharmacol. 2013, 35, 39-46. [CrossRef]

63. Kumar, S.R.; Hosokawa, M.; Miyashita, K. Fucoxanthin: A marine carotenoid exerting anti-cancer effects by affecting multiple mechanisms. Mar. Drugs 2013, 11, 5130-5147. [CrossRef]

64. Peng, J.; Yuan, J.-P.; Wu, C.-F.; Wang, J.-H. Fucoxanthin, a marine carotenoid present in brown seaweeds and diatoms: Metabolism and bioactivities relevant to human health. Mar. Drugs 2011, 9, 1806-1828. [CrossRef]

65. Kotake-Nara, E.; Asai, A.; Nagao, A. Neoxanthin and fucoxanthin induce apoptosis in PC-3 human prostate cancer cells. Cancer Lett. 2005, 220, 75-84. [CrossRef]

66. Méresse, S.; Fodil, M.; Fleury, F.; Chénais, B. Fucoxanthin, a marine-derived carotenoid from brown seaweeds and microalgae: A promising bioactive compound for cancer therapy. Int. J. Mol. Sci. 2020, 21, 9273. [CrossRef]

67. Li, Y.-X.; Himaya, S.W.A.; Kim, S.-K. Triterpenoids of marine origin as anti-cancer agents. Molecules 2013, 18, 7886-7909. [CrossRef] [PubMed]

68. Liby, K.T.; Yore, M.M.; Sporn, M.B. Triterpenoids and rexinoids as multifunctional agents for the prevention and treatment of cancer. Nat. Rev. Cancer 2007, 7, 357-369. [CrossRef] [PubMed]

69. Rabi, T.; Bishayee, A. Terpenoids and breast cancer chemoprevention. Breast Cancer Res. Treat. 2009, 115, 223-239. [CrossRef] [PubMed]

70. Gouveia, V.L.M.; Seca, A.M.L.; Barreto, M.C.; Neto, A.I.; Kijjoa, A.; Silva, A.M.S. Cytotoxic meroterpenoids from the macroalga Cystoseira abies-marina. Phytochem. Lett. 2013, 6, 593-597. [CrossRef]

71. Bouaicha, N.; Tringli, C.; Pesando, D.; Mallea, M.; Roussaki, C.; Verbist, J.F. Bioactive diterpenoids isolated from Dipophus ligulatus. Planta Med. 1993, 59, 256-258. [CrossRef] [PubMed] 
72. Sabry, O.M.M.; Andrews, S.; McPhail, K.L.; Goeger, D.E.; Yokochi, A.; LePage, K.T.; Murray, T.F.; Gerwicj, W.H. Neurotoxic meroditerpenoids from the tropical marine brown algae Stypopodium flabelliforme. J. Nat. Prod. 2005, 68, 1022-1030. [CrossRef]

73. Abatis, D.; Vagias, C.; Galanakis, D.; Norris, J.N.; Moreau, D.; Roussakis, C.; Roussis, V. Atomarianones A and B: Two cytotoxic meroditerpenes from the brown alga Taonia atomaria. Tetrahedron Lett. 2005, 46, 8525-8529. [CrossRef]

74. De Oliveira, L.S.; Tschoeke, D.A.; de Oliveira, A.S.; Hill, L.J.; Paradas, W.C.; Salgado, L.T.; Thompson, C.C.; Pereira, R.C.; Thompson, F.L. New Insights on the terpenome of the red seaweed Laurencia dendroidea (Florideophyceae, Rhodophyta). Mar. Drugs 2015, 13, 879-902. [CrossRef]

75. Irie, T.; Suzuki, M.; Masamune, T. Laurencin, a constituent from Laurencia species. Tetrahedron Lett. 1965, 6, 1091-1099. [CrossRef]

76. Sun, J.; Shi, D.-Y.; Li, S.; Wang, S.-J.; Han, L.-J.; Fan, X.; Yang, Y.-C.; Shi, J.-G. Chemical constituents of the red alga Laurencia tristicha. J. Asian Nat. Prod. Res. 2007, 9, 725-734. [CrossRef]

77. Zaleta-Pinet, D.A.; Holland, I.P.; Muñoz-Ochoa, M.; Murillo-Alvarez, J.I.; Sakoff, J.A.; van Altena, I.A.; McCluskey, A. Cytotoxic compounds from Laurencia pacifica, Org. Med. Chem. Lett. 2014, 4, 8. [CrossRef]

78. Antunes, E.M.; Afolayan, A.F.; Chiwakata, M.T.; Fakee, J.; Beukes, D.R. Identification and in vitro anti-esophageal cancer activity of a series of halogenated monoterpenes isolated from the South African seaweeds Plocamium suhrii and Plocamium cornutum. Phytochemistry 2011, 72, 769-772. [CrossRef]

79. Depix, M.S.; Martínez, J.; Santibañez, F.; Rovirosa, J.; San Martín, A.; Maccioni, R.B. The compound 14-keto-stypodiol diacetate from the algae Stypopodium flabelliforme inhibits microtubules and cell proliferation in DU-145 human prostatic cells. Mol. Cell. Biochem. 1998, 187, 191-199. [CrossRef] [PubMed]

80. Perry, N.B.; Blunt, J.W.; Munro, M.H.G. A cytotoxic and antifungal 1,4-naphthoquinone and related compounds from a New Zealand brown algae, Landsburgia quercifolia. J. Nat. Prod. 1991, 54, 978-985. [CrossRef]

81. Sansom, C.E.; Larsen, L.; Perry, N.B.; Berridge, M.V.; Chia, E.W.; Harper, J.L.; Webb, V.L. An antiproliferative bis-prenylated quinone from the new zealand brown alga Perithalia capillaris. J. Nat. Prod. 2007, 70, 2042-2044. [CrossRef] [PubMed]

82. Heo, S.-J.; Kim, K.-N.; Yoon, W.-J.; Oh, C.; Choi, Y.-U.; Affan, A.; Lee, Y.-J.; Lee, H.-S.; Kang, D.-H. Chromene induces apoptosis via caspase-3 activation in human leukemia HL-60 cells. Food Chem. Toxicol. 2011, 49, 1998-2004. [CrossRef] [PubMed]

83. Fisch, K.M.; Böhm, V.; Wright, A.D.; König, G.M. Antioxidative meroterpenoids from the brown alga Cystoseira crinita. J. Nat. Prod. 2003, 66, 968. [CrossRef] [PubMed]

84. Lefranc, F.; Kornienko, A.; Koutsaviti, A.; Roussis, V.; Newman, D. Algae metabolites: From in vitro growth inhibitory effects to promising anticancer activity. Nat. Prod. Rep. 2019, 36, 810-841. [CrossRef]

85. Hamdy, A.H.A.; Aboutabl, E.A.; Sameer, S.; Hussein, A.A.; Díaz-Marrero, A.R.; Darias, J.; Cueto, M. 3-Keto-22-epi-28-norcathasterone, a brassinosteroid-related metabolite from Cystoseira myrica. Steroids 2009, 74, 927-930. [CrossRef]

86. Sheu, J.H.; Wang, G.H.; Sung, P.J.; Chiu, Y.H.; Duh, C.Y. Cytotoxic sterols from the formosan brown alga Turbinaria ornata. Planta Med. 1997, 63, 571-572. [CrossRef]

87. Khanavi, M.; Gheidarloo, R.; Sadati, N.; Ardekani, M.R.; Nabavi, S.M.; Tavajohi, S.; Ostad, S.N. Cytotoxicity of fucosterol containing fraction of marine algae against breast and colon carcinoma cell line. Pharmacogn. Mag. 2012, 8, 60-64. [PubMed]

88. Pacheco, B.S.; Dos Santos, M.A.Z.; Schultze, E.; Martins, R.M.; Lund, R.G.; Seixas, F.K.; Colepicolo, P.; Collares, T.; Paula, F.R.; De Pereira, C.M.P. Cytotoxic Activity of Fatty Acids From Antarctic Macroalgae on the Growth of Human Breast Cancer Cells. Front. Bioeng. Biotechnol. 2018, 6, 185. [CrossRef] [PubMed]

89. Sheu, J.H.; Wang, G.H.; Sung, P.J.; Duh, C.Y. New cytotoxic oxygenated fucosterols from the brown alga Turbinaria conoides. J. Nat. Prod. 1999, 62, 224-227. [CrossRef] [PubMed]

90. Jiang, H.; Li, J.; Chen, A.; Li, Y.; Xia, M.; Guo, P.; Yao, S.; Chen, S. Fucosterol exhibits selective antitumor anticancer activity against HeLa human cervical cell line by inducing mitochondrial mediated apoptosis, cell cycle migration inhibition and downregulation of m-TOR/PI3K/Akt signalling pathway. Oncol. Lett. 2018, 15, 3458-3463. [CrossRef] [PubMed]

91. Bae, H.; Lee, J.-Y.; Song, G.; Lim, W. Fucosterol suppresses the progression of human ovarian cancer by inducing mitochondrial dysfunction and endoplasmic reticulum stress. Mar. Drugs 2020, 18, 261. [CrossRef] [PubMed]

92. Vishchuk, O.S.; Ermakova, S.P.; Zvyagintseva, T.N. Sulfated polysscharide from brown seaweeds sacchrina japonica and undaria pinnatifida: Isolation, structural characteristics, and antitumor activity. Carbohydr. Res. 2011, 346, 2769-2776. [CrossRef]

93. Park, H.Y.; Park, S.H.; Jeong, J.W.; Yoon, D.; Han, M.H.; Lee, D.S.; Choi, G.; Yim, M.J.; Lee, J.M.; Kim, D.H. Induction of p53-independent apoptosis and G1 cell cycle arrest by fucoidan in HCT116 human carcinoma cells. Mar. Drugs 2017, 15, 154-167. [CrossRef] 